\title{
Evidence of inhibin/activin subunit betaC and betaE synthesis in normal human endometrial tissue
}

\author{
Ioannis Mylonas ${ }^{1 *}$, Ansgar Brüning ${ }^{1}$, Naim Shabani ${ }^{1,2}$, Susanne Kunze ${ }^{1}$, Markus S Kupka
}

\begin{abstract}
Background: Inhibins are important regulators of the female reproductive system. Recently, two new inhibin subunits betaC and betaE have been described, although it is unclear if they are synthesized in normal human endometrium.

Methods: Samples of human endometrium were obtained from 82 premenopausal, non-pregnant patients undergoing gynecological surgery for benign diseases. Endometrium samples were classified according to anamnestic and histological dating into proliferative (day $1-14, n=46$ ), early secretory (day $15-22, n=18$ ) and late secretory phase (day 23-28, $n=18$ ). Immunohistochemical analyses were performed with specific antibodies against inhibin alpha $(n=81)$ as well as inhibin betaA $(n=82)$, betaB $(n=82)$, betaC $(n=74)$ and betaE $(n=76)$ subunits. RT-PCR was performed for all inhibin subunits. Correlation was assessed with the Spearman factor to assess the relationship of inhibin-subunits expression within the different endometrial samples.

Results: The novel inhibin betaC and betaE subunits were found in normal human endometrium by immunohistochemical and molecular techniques. Inhibin alpha, betaA, betaB and betaE subunits showed a circadian expression pattern, being more abundant during the late secretory phase than during the proliferative phase. Additionally, a significant correlation between inhibin alpha and all inhibin beta subunits was observed.

Conclusions: The differential expression pattern of the betaC- and betaE-subunits in normal human endometrial tissue suggests that they function in endometrial maturation and blastocyst implantation. However, the precise role of these novel inhibin/activin subunits in human endometrium is unclear and warrants further investigation.
\end{abstract}

\section{Background}

Together with bone morphogenetic proteins (BMPs), growth and differentiation factors (GDFs), myostatin, Muellerian inhibiting substance (MIS) and other proteins [1-3], inhibin and activin proteins belong to the transforming growth factor-beta (TGF- $\beta$ ) family of growth and differentiation factors. Within this inhibin subgroup, one $\alpha$-subunit and four $\beta$-subunit isoforms $(\beta \mathrm{A}, \beta \mathrm{B}, \beta \mathrm{C}$ and $\beta \mathrm{E})$ have been isolated in mammals and humans [2-6]. The $\beta$-subunits can form activins by dimerization with a second $\beta$-subunit, or alternatively, they can form inhibins by dimerizing with an $\alpha$-subunit. Thus, depending on the subunit combination, there are

\footnotetext{
* Correspondence: ioannis.mylonas@med.uni-muenchen.de

'Ludwig-Maximilians-University Munich, $1^{\text {st }}$ Department of Obstetrics and

Gynecology, Maistrasse 11, 80337 Munich, Germany

Full list of author information is available at the end of the article
}

two isoforms of inhibin (inhibin $A(\alpha-\beta A)$ and inhibin $B$ $(\alpha-\beta B))$ and three isoforms of activin (activin $A(\beta A-$ $\beta A)$, activin $B(\beta B-\beta B)$ and activin $A B(\beta A-\beta B))[2,3]$. Recently, two additional $\beta$-subunits were identified in humans, $\beta C$ [4] and $\beta E$ [6]. These two novel subunits share $82 \%$ and $61 \%$ amino acid sequence similarity with the corresponding mature proteins from rat and mouse, respectively $[7,8]$.

Inhibins and activins were initially isolated from the gonads and have been demonstrated to be disulfidelinked dimers [1-3]. Meanwhile, the well-studied inhibin $\alpha-, \beta A_{-}$, and $\beta B$-subunits have been detected in normal and abnormal endometrial tissue [9-15], and are implicated as important paracrine modulators of reproductive function [16,17] and malignant transformation $[12,13,18]$. Moreover, inhibins and activins might play an important role in endometrial cell function by 
regulating endometrial maturation, decidualization, and human implantation processes [19-26].

However, only limited data on histological expression of the inhibin/activin $\beta C$ and $\beta E$ subunits in normal human endometrium are available. The inhibin $\beta C$ protein was primarily expressed in human liver and prostate [27], while inhibin/activin $\beta E$ mRNA was predominantly synthesized in human liver with low levels found in heart, testis, leukocytes, and skeletal muscle [5]. Inhibin $\beta C$ was previously detected by immunohistochemical methods in normal and abnormal placenta $[28,29]$, endometrial cell lines [30,31], endometrial cancer [32], and cervical tissue [33]. Additionally, the inhibin $\beta E$ is synthesized in normal and abnormal placenta $[5,34,35]$ as well as human cervical tissue [36] and the endometrial cancer cell line Ishikawa [31].

Since specific monoclonal antibodies against inhibin subunits are only recently available, systematic investigations on the combined expression of inhibin/activin subunits have not been performed. Uncovering the differential expression patterns of the five inhibin/activin subunits and their correlations in human endometrium will further understanding of human reproduction. Additionally, knowledge of the expression patterns of the inhibin $\beta$-subunits is important, since activin signaling might be a promising target for therapeutic interventions [37].

\section{Methods}

\section{Tissue samples}

Immunohistochemical analysis of inhibin-subunits was performed on a well-characterized patient group $[11,38]$. Samples of human endometrium were obtained from 82 premenopausal, non-pregnant patients undergoing gynecological surgery for benign diseases (mainly uterine leiomyoma) either by $\mathrm{D} \& \mathrm{C}$ (dilatation and curettage) or hysterectomy. We had recently analyzed 54 endometrial samples for the expression of inhibin $-\alpha,-\beta A$ and $-\beta B$ [11], that have been included in this study. All women had a normal and regular menstrual cycle with no hormonal treatment for 3 months prior to surgery. All pathological and hyperplastic endometrial samples were excluded from this study. Endometrium samples were classified according to anamnestic and histological dating into proliferative (day $1-14, \mathrm{n}=46$ ), early secretory (day $15-22, \mathrm{n}=18$ ) and late secretory phase (day 23-28, $\mathrm{n}=18)$ as previously described $[11,38-40]$.

\section{Generation of a polyclonal inhibin- $\beta E$ peptide antibody}

Anti-inhibin $\beta E$ polyclonal antibodies were generated as custom-made antibodies in rabbits against a polypeptide of 16 amino acids of inhibin $\beta E$ (polypeptide-sequence: NH2-CRWGPRRRRQGSRTLL-COOH; amino acid position 144 to 158; accession number: AAH05161) as previously described by BioGenes (Berlin, Germany) [41].
This amino acid sequence is unique to the inhibin $\beta E$ subunit and is absent from other inhibin subunits. This, as well as optimal immunogenic properties, was checked prior to immunization by bioinformatic programs (Antheprot; protein sequence alignments) [34].

A primary dose of $200 \mu \mathrm{g}$ activin beta E polypeptide was solubilized in Freund's complete adjuvant (Sigma, Aldrich, Germany) and injected subcutaneously into rabbits. Three doses of the peptide solubilized in Freund's incomplete adjuvant were administrated at 6 week intervals. After the third booster injection (14 days), blood was collected from the rabbit, and the serum was separated. Antibodies were isolated by column chromatography with a protein A column (Amersham Pharmacia Biotech, Freiburg, Germany).

\section{Immunohistochemistry}

Immunohistochemical analyses were performed using a combination of heat induced antigen retrieval and the standard streptavidin-biotin-peroxidase complex using the mouse (for the inhibin $\alpha, \beta \mathrm{A}$ and $\beta \mathrm{B}$ antibodies), goat (for inhibin $\beta C$ antibody) or rabbit (for inhibin $\beta E$ antibody) IgG-Vectastain Elite ABC kit (Vector Laboratories, Burlingame, California, USA) as previously described $[11,31,34,36,41]$.

Antibodies used for these experiments are listed in Table 1. The immunohistochemical procedures for inhibin $\alpha-, \beta A$ - and $\beta B$-subunits were evaluated in normal and malignant endometrial tissue [11-13,42,43], breast cancer tissue [44], and uterine cervical cancer [45] as well as normal and abnormal placenta [46,47]. The inhibin $\beta C$ antibody was previously evaluated in normal and pathological placenta tissue $[28,29]$, endometrial cell lines [30,31], endometrial cancer [32] and cervical tissue [33]. The immunohistochemical procedure for inhibin $\beta E$ was performed in ovarian tissue [41], endometrial cancer cell lines [31], normal and abnormal placenta [34], and uterine cervical tissue [36].

Briefly, paraffin-fixed tissue sections were dewaxed using xylol for $15 \mathrm{~min}$, rehydrated in descending series of alcohol (100\%, 96\% and 70\%), and subjected to antigen retrieval for $10 \mathrm{~min}$ in a pressure cooker using sodium citrate buffer ( $\mathrm{pH} 6.0$ ), containing $0.1 \mathrm{M}$ citric acid and $0.1 \mathrm{M}$ sodium citrate in distillated water. After reaching room temperature, sections were washed twice in phosphate-buffered saline (PBS). Endogenous peroxidase activity was quenched by immersion in 3\% hydrogen peroxide (Merck, Darmstadt, Germany) in methanol for $20 \mathrm{~min}$. Non-specific binding of the primary antibodies was blocked by incubating the sections with diluted normal serum $(10 \mathrm{ml}$ PBS containing $150 \mu \mathrm{l}$ horse serum; provided by Vector Laboratories) for $20 \mathrm{~min}$ at room temp. Sections were then incubated at room temperature for $60 \mathrm{~min}$ with the primary antibodies for 
Table 1 Antibodies used for immunohistochemical characterization of human endometrium

\begin{tabular}{|c|c|c|c|c|c|}
\hline Antibody & Clone & Isotype & Dilution & Dilution medium & Source \\
\hline Inhibin- $\alpha$ & R1 & Mouse lgG2a & $1: 50$ & PBS & Serotec, Oxford, UK \\
\hline Inhibin- $\beta A$ & E4 & Mouse lgG2b & $1: 50$ & PBS & Serotec, Oxford, UK \\
\hline Inhibin- $\beta B$ & C5 & Mouse lgG2a & $1: 10$ & PBS & Serotec, Oxford, UK \\
\hline Inhibin- $\beta C$ & Polyclonal & Goat lgG & $1: 50$ & Ultra-V-Block & R\&D Systems, Wiesbaden, Germany \\
\hline Inhibin- $\beta E$ & Polyclonal & Rabbit lgG & $1: 4000$ & Ultra-V-Block & BioGenes, Berlin, Germany \\
\hline
\end{tabular}

inhibin- $\alpha,-\beta A$ and $-\beta B$. Inhibin $-\alpha,-\beta A$ and $-\beta B$ were diluted in PBS. For inhibin- $\beta C$ and $-\beta E$ antibodies, sections were incubated at $4 \mathrm{C}$ over night with the inhibin$\beta C$ polyclonal goat antibody at a dilution of 1:50 in Ultra-V-Block (Lab Vision, Fremont, U.S.A.) or the inhibin- $\beta E$ polyclonal rabbit antibody at a dilution of 1:4000 in Ultra-V-Block (Lab Vision, Fremont, U.S.A.). After washing with PBS, sections were incubated in diluted biotinylated serum $(10 \mathrm{ml}$ PBS containing $50 \mu$ l horse serum; provided by Vector Laboratories) for $30 \mathrm{~min}$ at room temperature. After incubation with the avidin-biotin peroxidase complex (diluted in $10 \mathrm{ml}$ PBS; Vector Laboratories) for $30 \mathrm{~min}$ and repeated washing steps with PBS, visualization was performed with substrate and chromogen 3,3'-diaminobenzidine (DAB; Dako, Glostrup, Denmark) for 8-10 min. Sections were counterstained with Mayer's acidic hematoxylin and dehydrated in an ascending series of alcohol (50-98\%). After xylol treatment, sections were covered. Negative controls were performed by replacing the primary antibody with normal mouse, rabbit or goat IgG as isotype control in the same dilution compared to the primary antibody, respectively. Immunohistochemical staining was performed using an appropriate positive control comprising ovaries containing follicular cysts $[11,31,41]$. Positive cells showed a brownish color and negative controls as well as unstained cells were blue. Sections were examined using a Leitz (Wetzlar, Germany) photomicroscope. Digital images were obtained with a digital camera system (JVC, Japan) and were saved on computer (Diskus software, Hilgers, Königswinter, Germany).

\section{RT-PCR analysis}

To analyze inhibin subunit expression at the transcriptional level, RNA was extracted from samples of human endometrium tissue of proliferative $(\mathrm{n}=3)$ and secretory phase $(\mathrm{n}=3)$ cells, transcribed into cDNA, and analyzed by RT-PCR analysis for the expression of inhibin subunits $\alpha, \beta \mathrm{A}, \beta \mathrm{B}, \beta \mathrm{C}$ and $\beta \mathrm{E}$ using specific primers (Table 2).

RNA was extracted from cells using the Nucleospin RNA II kit (Macherey-Nagel, Düren, Germany) as previously described $[29,31,34,36]$. Reverse transcription was performed with M-MLV reverse transcriptase and oligo-dT (Promega, Mannheim, Germany) as recommended by the supplier. PCR was performed in an Eppendorf Mastercycler with GoTaq (Promega, Mannheim, Germany). Primer sequences are listed in Table 2. PCR cycling was performed after a $5 \mathrm{~min}$ initiation at $94^{\circ} \mathrm{C}$ with 36 cycles of $1 \mathrm{~min}$ at $94^{\circ} \mathrm{C}, 1 \mathrm{~min}$ at $57^{\circ} \mathrm{C}, 2$ min at $72^{\circ} \mathrm{C}$, followed by a 5 min extension at $72^{\circ} \mathrm{C}$. For a cDNA quality control, actin primers (Stratagene, The Netherlands), amplifying a 661 bp product, were used. As a further control, cDNA was omitted (water control) to present any PCR contaminations [29]. PCR products were separated on a $1.5 \%$ agarose gel, including a pBR328 marker (Roth, Karlsruhe, Germany). Gels were stained with SYBR Safe (1:10,000 dilution; Invitrogen, Karlsruhe, Germany) prior to gel electrophoresis and after a completed run transferred on a UV-permeable tray to a BioRad Image Analyser (BioRad, Munich, Germany) [29]. The generated electronic picture file was exported as a TIFF file and imported in a Power-Point presentation file in order to crop and label the figure.

\section{Evaluation and statistical analysis}

The intensity and distribution patterns of specific inhibin $-\alpha,-\beta A,-\beta B,-\beta C$ and $-\beta E$ subunit immunohistochemical staining was evaluated using the semiquantitative score (IRS) as previously described and

Table 2 Primer sequences and length of amplification products

\begin{tabular}{|c|c|c|c|}
\hline & Forward primer $\left(5^{\prime}-3^{\prime}\right)$ & Backward primer $\left(3^{\prime}-5^{\prime}\right)$ & Length \\
\hline Inhibin- $\alpha$ & CCGGCCATCCCAGCATACACGC & GAGTTGAGCGTCGGGCTCTC & $359 \mathrm{bp}$ \\
\hline Inhibin- $\beta A$ & TGCCCTTGCTTTGGCTGAGA & ACTTTGCCCACATGAAGCTTT & $282 \mathrm{bp}$ \\
\hline Inhibin- $\beta B$ & GGCGAGCGGCGACTCAACCTAGA & CGTGTGGAAGGAGGAGGCAGAGC & $333 \mathrm{bp}$ \\
\hline Inhibin- $\beta C$ & GCAGCCCGGGTGAGAGTTGG & ACTGCACCCACAGGCCTC & $393 \mathrm{bp}$ \\
\hline Inhibin- $\beta E$ & AGCCCTTCCTAGAGCTTAAG & GCTGCAGCCACAGGCC & $404 \mathrm{bp}$ \\
\hline
\end{tabular}

$\mathrm{bp}=$ base pairs 
used to asses inhibin/activin subunits [11,13]. Briefly, the IRS score was calculated by multiplication of optical staining intensity (graded as $0=$ no, $1=$ weak, $2=$ moderate and $3=$ strong staining) by the percentage of positive stained cells $(0=$ no staining, $1=<10 \%$ of the cells, $2=11-50 \%$ of the cells, $3=51-80 \%$ of the cells and $4=$ $>81 \%$ of the cells). The slides were examined by two independent observers, including a gynecological pathologist (N.S.). Sections were examined using a Leitz (Wetzlar, Germany) photomicroscope. Digital images were obtained with a digital camera system (JVC, Yokohama, Japan) and were saved on computer (Diskus software, Hilgers, Königswinter, Germany). The results were evaluated using the non-parametric Mann-Whitney U rank-sum test (SPSS, Version 17.0, Chigaco, IL, USA). Correlation was assessed with the Spearman factor to assess the relationship of inhibin-subunits expression within the different endometrial samples. Significance was assumed at $\mathrm{p}<0.05$ by using the two-tailed test.

\section{Results}

\section{Immunohistochemical expression of inhibin- $\alpha,-\beta A,-\beta B$, $-\beta C$ and $-\beta E$}

To test the antibodies against the $\beta C$ - and $\beta E$-subunits, evaluation of the immunohistochemical staining reaction was performed using appropriate positive controls, including normal liver specimens (Figure 1a-b) and previous results were confirmed $[5,29,31,34,36,41,48]$. The inhibin/activin $\alpha-, \beta \mathrm{A}_{-}$, and $\beta \mathrm{B}$-subunits were detected in normal human endometrial tissue throughout the menstrual cycle in accord with previous results (data not shown). Inhibin $\alpha, \beta \mathrm{A}$, and $\beta \mathrm{B}$ were primarily observed in glandular and luminal epithelial cells, with a different staining intensity in stromal cells, especially during secretory phase. Proliferative and secretory endometria expressed the $\beta \mathrm{A}$ - and $\beta \mathrm{B}$-subunits with a similar pattern with the maximal immunostaining intensity observed in secretory phase tissues (data not shown) (Table 3) [11,15].

The $\beta C$-subunit was also detected in endometrial glandular epithelial cells. A diffuse immunohistochemical staining reaction was observed in cells representing all stages of the menstrual cycle. The staining intensity of cells was weaker during early secretory phase (Figure 2b) compared to the cells from endometrial samples from proliferative phase (Figure 2a), while the maximal immunostaining reaction was observed in cells isolated from late secretory phase tissues (Figure 2c). Interestingly, the $\beta C$-subunit immunoreactivity was detected in all stages of the menstrual cycle examined with little variation in intensity. (Figure 2c).

The inhibin $\beta E$-subunit was also expressed in human endometrium primarily in the glandular and surface epithelium. During proliferative phase, minimal

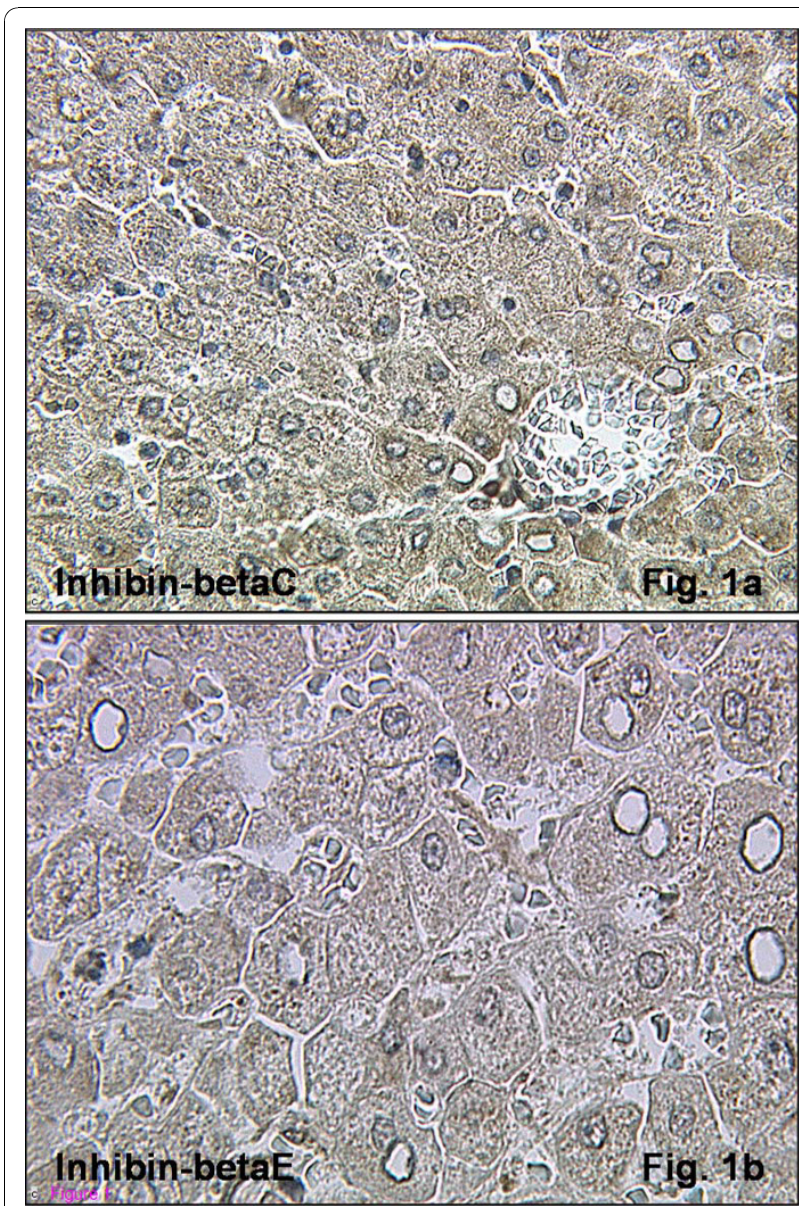

Figure $1 \mathrm{Immunohistochemical} \mathrm{expression} \mathrm{of} \mathrm{inhibin-} \beta C$ and $-\beta E$ in normal liver tissue. Inhibin- $\beta C$ (Figure 1a; magnification $\times 400$ ) and $\beta E$ (Figure $1 \mathrm{~b}$; magnification $\times 400$ ) subunit demonstrated a positive staining reaction in normal human liver tissue.

immunoreactivity was observed at the apical component of glandular cells (Figure 3a). The staining intensity increased in tissues from the early secretory phase, and was localized to the basal and apical components of the cells (Figure $3 \mathrm{~b}$ ). The strongest immunoreactivity was observed during late secretory phase (Figure 3c). With the onset of early secretory phase, the $\beta E$-subunit was also detected in stromal cells (Table 3) (Figure 3c). However, no statistically significant differences in immunoreactivity found in stromal cells was observed for inhibin $\beta C$ and $\beta E$ at any stage of the menstrual cycle (data not shown).

\section{RT-PCR analysis}

Figure 4 demonstrates that the mRNA of all inhibin subunits is expressed in normal human endometrium tissue of the secretory phase (Figure 4a) as well as of the proliferative phase (Figure $4 \mathrm{~b}$ ). Overall, the expression of inhibin subunit mRNAs appeared to be higher in the 
Table 3 Immunohistochemical findings determining localization and intensity of immunostaining intensity for inhibin- $\alpha,-\beta A,-\beta B,-\beta C$ and $-\beta E$ subunits in human endometrium across the normal menstrual cycle

\begin{tabular}{lcccc}
\hline & Inhibin subunits & Proliferative phase & Early secretory phase & Late secretory phase \\
\hline Glandular epithelium & $\alpha$ & + & + & + \\
& $\beta \mathrm{A}$ & + & + & + \\
& $\beta \mathrm{B}$ & + & + & + \\
& $\beta \mathrm{C}$ & + & + & + \\
Stromal cells & $\beta \mathrm{E}$ & + & + & + \\
& $\alpha$ & - & + & + \\
& $\beta \mathrm{A}$ & - & + & + \\
& $\beta \mathrm{B}$ & - & + & + \\
& $\beta \mathrm{E}$ & + & + & + \\
\end{tabular}

- = no staining; $+/-=$ minimal staining $+=$ positive staining $;++=$ intense staining.

secretory phase than in the proliferative phase, although the small sample number and activities of potential regulatory mechanisms at the post-transcriptional level did not allow further conclusions to be drawn.

\section{Statistical analysis}

A statistically significant correlation between the immunoreactive score (IRS) of the inhibin $\alpha$ and all inhibin $\beta$ subunits was observed by using the non-parametric Spearmen correlation factor $(\mathrm{p}<0.05)$. However, no significant correlation between the amount of the $\beta C$-subunit and the amount of the other $\beta$-subunits was demonstrated. The IRS of the inhibin $\beta E$-subunit showed a significant association with the amount of the inhibin $\beta$ B-subunit $(\mathrm{p}<0.05)$ (Table 4$)$.

The immunoreactive score for inhibin $\beta \mathrm{A}, \beta \mathrm{B}$ and $\beta \mathrm{E}$ increased between proliferative and late secretory phase $(\mathrm{p}<0.05)$ as well as between early and late secretory phase $(\mathrm{p}<0.05)$ (Figure 5). Inhibin $\alpha$ expression was higher during late secretory phase compared to proliferative endometrial tissue $(\mathrm{p}<0.05)$, while the immunoreactive score for inhibin $\beta C$ did not demonstrate any changes during the menstrual cycle (Figure 5).

\section{Discussion}

Inhibin-subunits in human endometrium

Inhibins and activins were initially characterized as endocrine and paracrine hormonal regulators of the hypothalamic-pituitary-gonadal axis. Several autocrine and paracrine actions of inhibins/activins have been reported including modulation of ovarian and placental hormone secretion $[17,21,49,50]$, decidualization [21-24,51], and trophoblast differentiation [20,52], as well as effects on immunomodulatory function [53], stem cell biology [54,55], and apoptosis [56]. However, these putative functions have been characterized for inhibin $\alpha, \beta \mathrm{A}$ and $\beta \mathrm{B}$ isoforms, and it is not clear if the $\beta C$ - and $\beta E$ - isoforms have similar function.
Meanwhile, these proteins are expressed in a wide range of female reproductive tissues including normal and abnormal human endometrium $[9,10,12,13,15,42,43]$. In this study, a circadian expression of the well-known inhibin $\alpha-, \beta \mathrm{A}-$, and $\beta \mathrm{B}$-subunits in normal human endometrial tissue was demonstrated, confirming previous results $[10,11]$. Moreover, expression of the novel inhibin/activin $\beta C$ - and $\beta E$-subunits was also demonstrated in normal human endometrium by using RT-PCR and immunohistochemical detection methods. The $\beta \mathrm{E}$-subunit demonstrated an increase in staining intensity between proliferative and late secretory phase similar to results with inhibin $\alpha, \beta \mathrm{A}$ and $\beta \mathrm{B}$ immunolabeling. By contrast, the $\beta C$-subunit did not show any difference in immunohistochemical staining intensity between proliferative and secretory phase. A decrease of the inhibin $\beta C$-subunit staining intensity was demonstrated between proliferative and late secretory phase, but this was not statistically significant.

The inhibins $\alpha, \beta \mathrm{A}$ and $\beta \mathrm{B}$ probably have important functions in blastocyst implantation and contribute to the paracrine signaling needed for adequate endometrial maturation [22]. The potential roles of the novel inhibin/activin subunits in human reproduction are intriguing. Results suggest that both $\beta C$ - and $\beta E$-subunits also play an important role in the human menstrual cycle. Additionally, the distinct expression of inhibin- $\alpha$ in the apical part of the glandular epithelial cells shows the preferred synthesis of inhibins in the uterine lumen. Since expression is lower in the endometrial stroma, activins are probably produced and secreted into this compartment [11].

Inhibin $\beta C$-subunit

Inhibin $\beta C$ was primarily detected in hepatocytes $[5,48]$ and is implicated in the regulation of liver cell growth as demonstrated by downregulation of inhibin $\beta C$ mRNA after partial hepatectomy in rats $[57,58]$. 

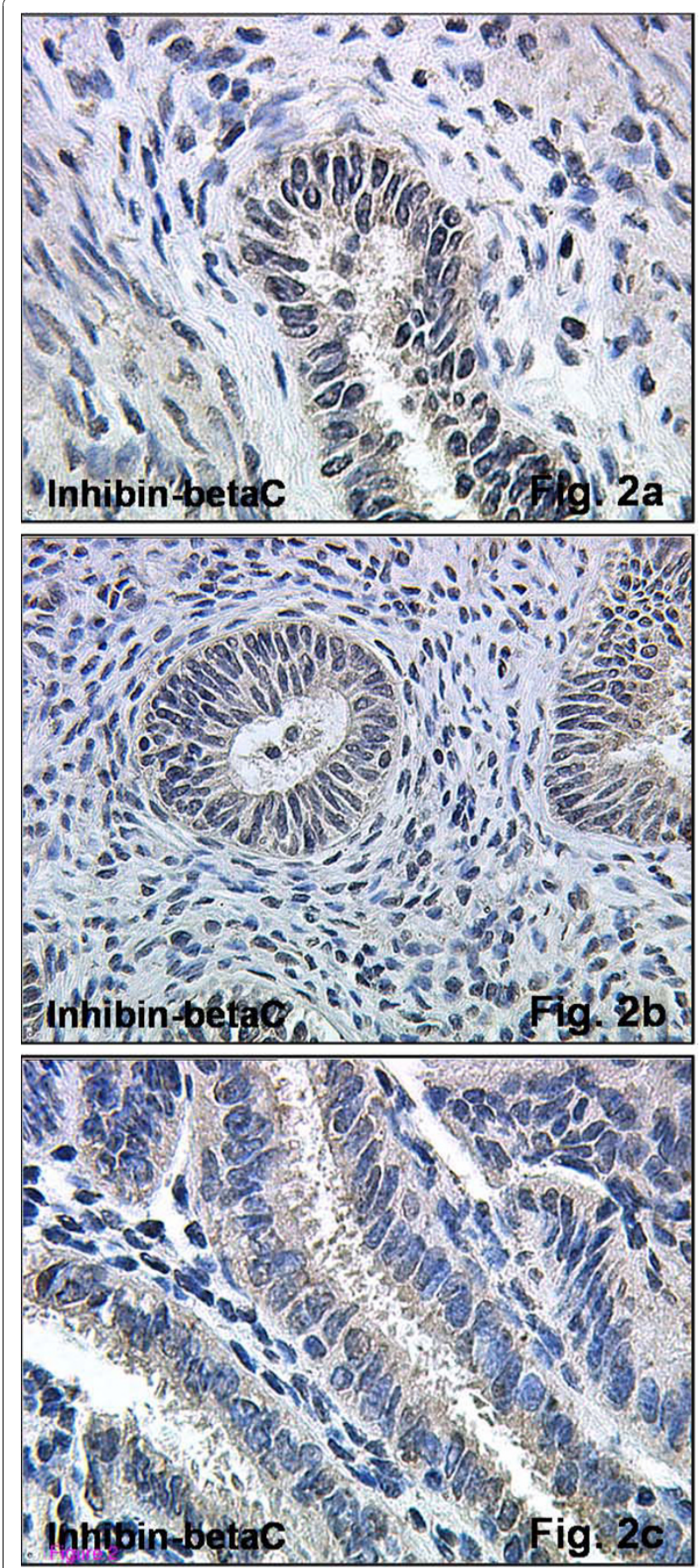

Figure 2 Immunohistochemical expression of inhibin- $\beta C$ in normal human endometrial tissue. Immunohistochemical staining reaction for inhibin- $\beta C$ could be observed across the menstrual cycle. Proliferative (Figure 2a, magnification $\times 250$ ) and early secretory endometria (Figure $2 \mathrm{~b}$, magnification $\times 125$ ) expressed this subunit, but with a weak intensity. The strongest staining intensity could be observed during tissue samples late secretory phase

(Figure 2c, magnification $\times 400$ ). Stromal cells also reacted positively throughout the menstrual cycle.
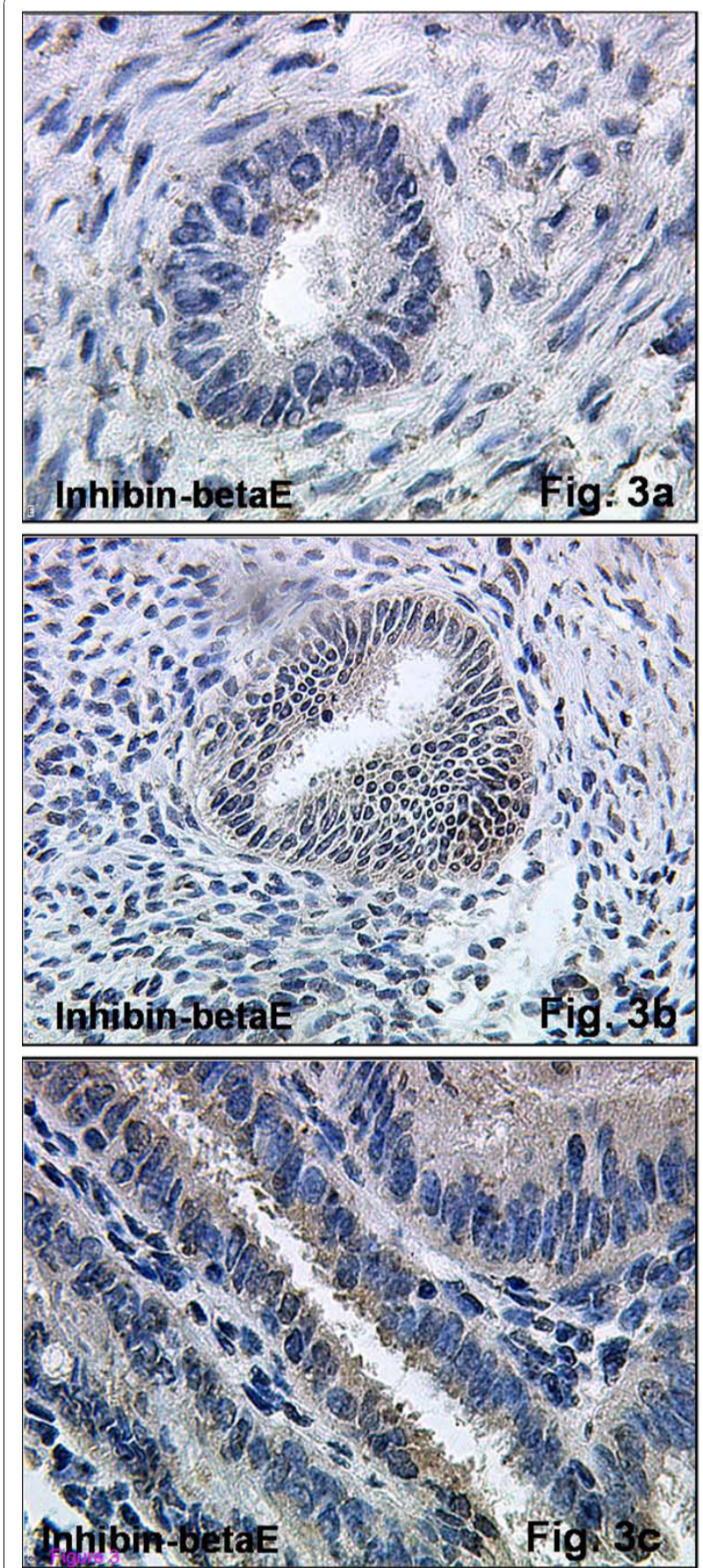

Figure $3 \mathrm{Immunohistochemical} \mathrm{expression} \mathrm{of} \mathrm{inhibin-} \beta E$ in normal human endometrial tissue. Immunohistochemical staining reaction for inhibin- $\beta$ E could be observed across the menstrual cycle. Proliferative endometrial tissue (Figure 3a, magnification $\times 250$ ) demonstrated a weak staining intensity, while this intensity increased during early (Figure 3b, magnification $\times 125$ ) and late secretory endometria. The strongest staining intensity could be observed during tissue samples late secretory phase (Figure 3c, magnification $\times 400$ ). Stromal cells also reacted positively with a minimal staining intensity in the proliferative phase, being moist prominent during late secretory phase. 


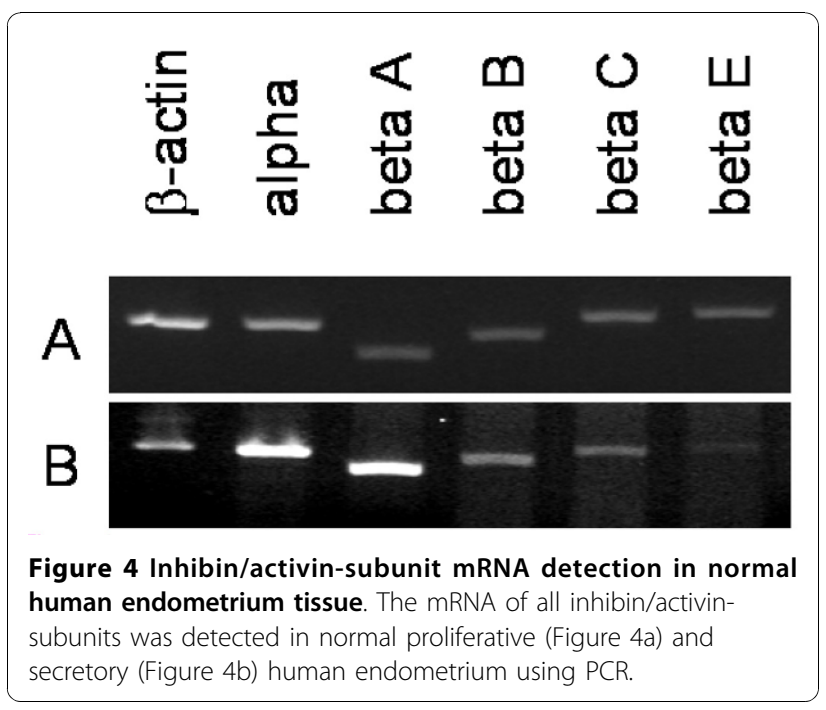

The formation of homodimeric activin $C(\beta C-\beta C)$, heterodimeric activins $A C(\beta A-\beta C), B C(\beta B-\beta C), C E(\beta C$ $\beta E)$, and inhibin $C(\alpha-\beta)$ has been demonstrated by ectopic expression of the respective subunits in different cell models $[27,59]$. Although the precise role of the $\beta C$ subunit has not been elucidated, several possible functions have been suggested. Interestingly, ectopic expression of inhibin/activin $\beta C$ subunit induced apoptosis in human (HepG2, Hep3B) and rat (H4, EC3) hepatoma cells $[60,61]$. In an immortalized mouse hepatocyte cell line (AML12) and primary rat hepatocytes, activin $\beta C$ increased the rate of DNA synthesis [62]. Moreover, the $\beta C$-subunit was identified as an autocrine growth modulator in liver regeneration, leading to mitosis in a subset of hepatocytes [63].
In human reproduction, this $\beta C$ subunit is not believed to be a significant regulator of activin bioactivity, since no abnormalities or malformations have been observed in inhibin- $\beta C$ knockout mice [48]. However, there might be functional redundancy with other TGF- $\beta$ factors [64] and an antagonistic and regulatory role for activin A bioactivity has recently been proposed $[27,64,65]$. Interestingly, activin $C(\beta C-\beta C)$ did not activate activin $A(\beta A-\beta A)$ responsive promoters, and it was suggested that the $\beta C$-subunit regulates the levels of bioactive activin $A$ ( $\beta A-\beta A)$ through the formation of signaling incompetent activin AC heterodimers [64-66].

A preliminary study using RT-PCR and immunohistochemical detection methods demonstrated expression of inhibin $\beta C$ in normal human endometrium and the human endometrial carcinoma cell line Ishikawa [31]. The lower expression observed during early secretory phase compared to that found in the proliferative phase might suggest a mitotic function [63]. Thus, inhibin $\beta C$ might participate in the proliferation of human endometrium during the first phase of the menstrual cycle and reduce the mitotic effect during blastocyst implantation. However, no significant differences in $\beta C$-subunit expression during the menstrual cycle were found. This might be attributed either to the antibody used or to the small number of samples analyzed. In addition, the expression pattern of this subunit is different from the other $\beta$-subunits, and this suggests that it may have a different function in human endometrium.

\section{Inhibin $\beta E$-subunit}

Similar to the $\beta C$-subunit, the $\beta E$-subunit is predominantly expressed in hepatocytes, although it is also detected in human heart, testis, peripheral blood

Table 4 Correlation between all five inhibin-subunits

\begin{tabular}{|c|c|c|c|c|c|c|}
\hline & & Inhibin- $\alpha$ & inhibin- $\beta A$ & inhibin- $\beta B$ & Inhibin- $\beta C$ & Inhibin- $\beta E$ \\
\hline \multirow[t]{3}{*}{ Inhibin- $\alpha$} & Correlation Coefficient ( $r$ ) & & 0,409 & 0,534 & 0,260 & 0,533 \\
\hline & $p$ & & $<0,001$ & $<0,001$ & $<0,05$ & $<0,001$ \\
\hline & $n$ & & 81 & 80 & 73 & 75 \\
\hline \multirow[t]{3}{*}{ inhibin- $\beta A$} & Correlation Coefficient (r) & 0,409 & & 0,539 & 0,097 & 0,209 \\
\hline & $p$ & $<0,001$ & & $<0,001$ & N.S. & N.S. \\
\hline & $n$ & 81 & & 81 & 74 & 76 \\
\hline \multirow[t]{3}{*}{ inhibin- $\beta B$} & Correlation Coefficient (r) & 0,534 & 0,539 & & 0,231 & 0,321 \\
\hline & $p$ & $<0,001$ & $<0,001$ & & $=0,05$ & $<0,01$ \\
\hline & $n$ & 80 & 81 & & 73 & 75 \\
\hline \multirow[t]{3}{*}{ Inhibin- $\beta C$} & Correlation Coefficient (r) & 0,260 & 0,097 & 0,231 & & 0,027 \\
\hline & $p$ & $<0,05$ & N.S. & $=0,05$ & & N.S. \\
\hline & $n$ & 73 & 74 & 73 & 74 & 69 \\
\hline \multirow[t]{3}{*}{ Inhibin- $\beta E$} & Correlation Coefficient (r) & 0,533 & 0,209 & 0,321 & 0,027 & \\
\hline & $p$ & $<0,001$ & $<0,05$ & $<0,01$ & N.S. & \\
\hline & $n$ & 75 & 76 & 75 & 69 & \\
\hline
\end{tabular}




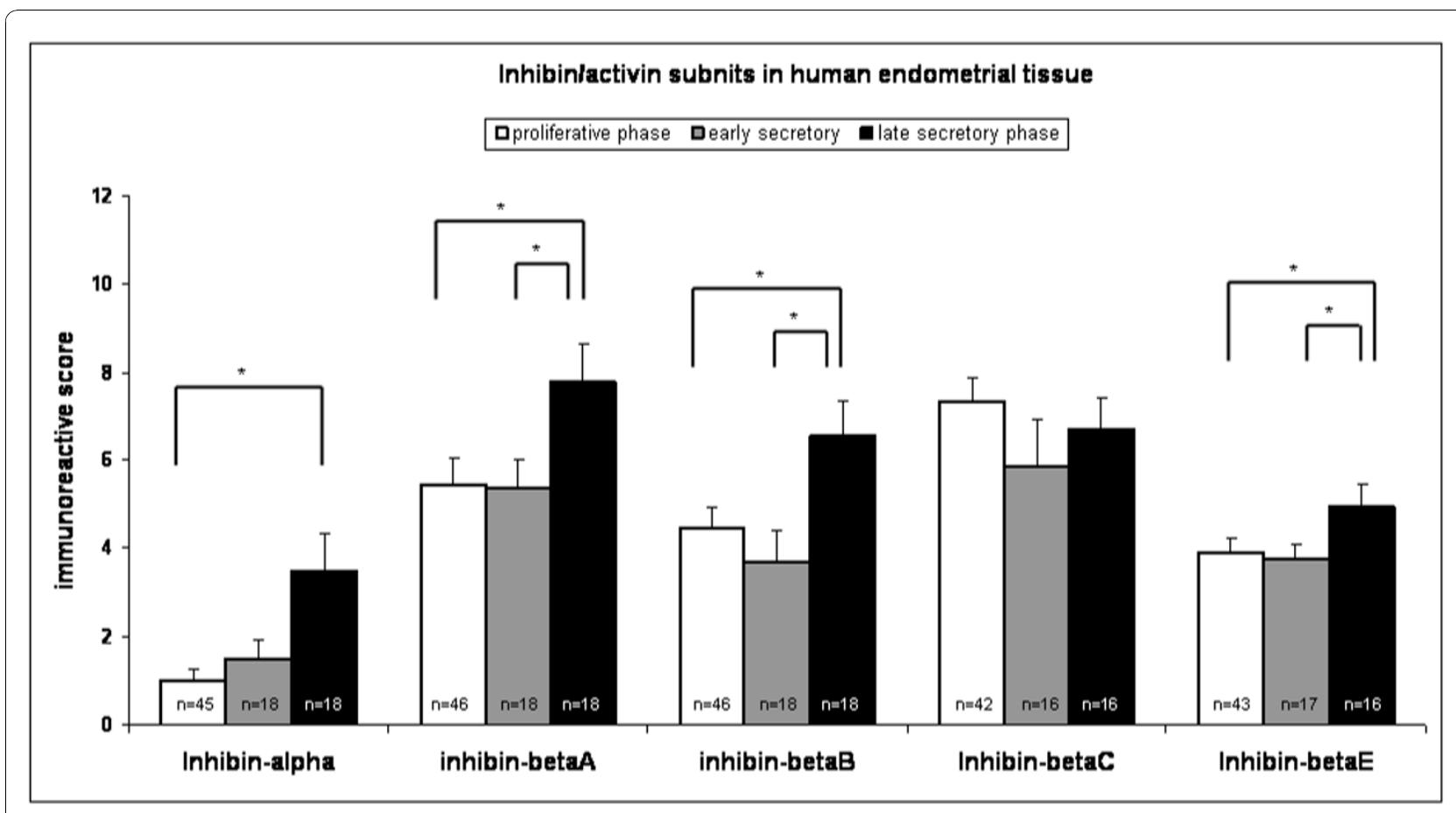

Figure $5 \mathrm{Immunohistochemical} \mathrm{score} \mathrm{for} \mathrm{the} \mathrm{expression} \mathrm{of} \mathrm{all} \mathrm{five} \mathrm{analyzed} \mathrm{inhibin/activin} \mathrm{subunits.} \mathrm{The} \mathrm{immunohistochemical} \mathrm{staining}$ reaction for inhibin- $\alpha$ was significantly lower during proliferative compared to late secretory phase. Moreover, the immunohistochemical expression of the inhibin $-\beta \mathrm{A},-\beta \mathrm{B}$, and $-\beta \mathrm{E}$ were significantly higher during late secretory compared to proliferative and early secretory phase $\left(^{*}\right)$. Inhibin- $\beta C$, although being lower during early secretory phase, did not demonstrate any significant changes throughout the menstrual cycle. Values represent means \pm SEM. Significance was assumed at $p<0.05$ (asterisks).

leucocytes, and skeletal muscle tissue [5,6,61,67]. Moreover, inhibin $\beta E$ is synthesized in normal and abnormal placenta [5,34,35] and human cervix [36]. This novel subunit was also demonstrated in the Ishikawa endometrial carcinoma cell line, which suggests that these cells may be useful as an in vitro model for studying the $\beta E$ subunit [31].

Formation of homodimeric activin $\mathrm{E}$ as well as heterodimeric activins $\mathrm{AE}(\beta \mathrm{A}-\beta \mathrm{E})$ and $\mathrm{CE}(\beta \mathrm{C}-\beta \mathrm{E})$ has been demonstrated after ectopic co-expression of these respective subunits $[5,8]$. Interestingly, inhibin/activin $\beta E$ mRNA expression was transiently upregulated after partial hepatectomy or portal vein branch ligation $[48,68]$. When ectopically expressed in HepG2 or Hep3B hepatoma cells or in the murine hepatocyte cell line AML12, activin $\beta E$ reduced the cell number and increased apoptosis rates [61,62]. Moreover, transient overexpression of $\beta E$ by non-viral gene transfer in mouse liver inhibited regenerative DNA synthesis [60].

These observations suggest that activin E may have a growth limiting function similar to activin A [69]. However, the apoptotic function of the $\beta E$ subunit in human endometrial tissue remains unclear. The observed increase in immunohistochemical staining of this subunit during late secretory phase is similar to the increase found for the $\beta \mathrm{A}$-and $\beta \mathrm{B}$-subunits [11] and suggests they all could have a similar function. However, the functions of these novel subunits and the formation of putative inhibins and/or activins warrants further research.

\section{Conclusions}

In conclusion, the inhibin $\beta C$ - and $\beta E$-subunits were expressed by normal human endometrial tissue. The immunolabeling of inhibin $\beta E$ in human endometrium varied with the different stages of the menstrual cycle while the synthesis of the $\beta C$-subunit did not. Although the results show that epithelial cells are the predominant source of these subunits in normal endometrium, they were also detected in endometrial stroma throughout the menstrual cycle. The differential expression pattern of these $\beta$-subunits suggests that they have an important function in endometrial maturation and blastocyst implantation. Moreover, they probably participate in the paracrine signaling necessary for adequate endometrial maturation.

\section{Acknowledgements}

We would like to thank Mrs. C. Kuhn, Mrs. S. Kunze, Mrs S. Schulze, Mrs. I. Wiest, Prof. U. Jeschke and Prof. K. Friese for their excellent work with the 
endometrial samples and their support. This study was partially supported by the FoeFoLe program of the Ludwig-Maximilians-University Munich (297/ 03), the Friedrich-Baur-Institute Munich and the Weigland Stipendium Program of the Ludwig-Maximilians-University Munich for I. Mylonas. I. Mylonas and A. Brüning are founded by the German Research Foundation (Deutsche Forschungsgemeinschaft, DFG BR 3641/3-1).

\section{Author details}

${ }^{1}$ Ludwig-Maximilians-University Munich, $1^{\text {st }}$ Department of Obstetrics and Gynecology, Maistrasse 11, 80337 Munich, Germany. ${ }^{2}$ Department of Obstetrics and Gynecology, Klinikum Neuperlach, Munich, Germany.

\section{Authors' contributions}

I.M. and M.S.K. carried out the data collection and data analysis, and drafted the manuscript. The study was conceived by I.M., who performed also the statistical analysis. A.B. participated in the design of the study and performed the PCR analysis. I.M. and N.S. participated in the histological evaluation of endometrial samples. S.K. performed the immunohistochemistry for all inhibin-subunits. All authors have read and approved the final manuscript.

\section{Competing interests}

The authors declare that they have no competing interests.

Received: 21 June 2010 Accepted: 19 November 2010

Published: 19 November 2010

\section{References}

1. Chang $\mathrm{H}$, Brown CW, Matzuk MM: Genetic analysis of the mammalian transforming growth factor-beta superfamily. Endocr Rev 2002, 23(6):787-823

2. Vale W, Wiater E, Gray P, Harrison C, Bilezikjian L, Choe S: Activins and inhibins and their signaling. Ann N Y Acad Sci 2004, 1038:142-147.

3. Xia $Y$, Schneyer AL: The biology of activin: recent advances in structure, regulation and function. J Endocrinol 2009, 202(1):1-12.

4. Hötten G, Neidhardt H, Schneider C, Pohl J: Cloning of a new member of the TGF-beta family: a putative new activin beta $C$ chain. Biochem Biophys Res Commun 1995, 206(2):608-613.

5. Hashimoto O, Tsuchida K, Ushiro $Y$, Hosoi $Y$, Hoshi N, Sugino $H$, Hasegawa $Y$ : cDNA cloning and expression of human activin betaE subunit. Mol Cell Endocrinol 2002, 194(1-2):117-122.

6. Fang J, Yin W, Smiley E, Wang SQ, Bonadio J: Molecular cloning of the mouse activin beta E subunit gene. Biochem Biophys Res Commun 1996, 228(3):669-674.

7. Fang J, Wang SQ, Smiley E, Bonadio J: Genes coding for mouse activin beta $C$ and beta $E$ are closely linked and exhibit a liver-specific expression pattern in adult tissues. Biochem Biophys Res Commun 1997. 231(3):655-661.

8. Vejda S, Cranfield M, Peter B, Mellor SL, Groome N, Schulte-Hermann R, Rossmanith $\mathrm{W}$ : Expression and dimerization of the rat activin subunits betaC and betaE: evidence for the ormation of novel activin dimers. $J$ Mol Endocrinol 2002, 28(2):137-148.

9. Petraglia F, Florio P, Luisi S, Gallo R, Gadducci A, Vigano P, Di Blasio AM, Genazzani AR, Vale W: Expression and secretion of inhibin and activin in normal and neoplastic uterine tissues. High levels of serum activin $A$ in women with endometrial and cervical carcinoma. J Clin Endocrinol Metab 1998, 83(4):1194-1200.

10. Leung PH, Salamonsen LA, Findlay JK: Immunolocalization of inhibin and activin subunits in human endometrium across the menstrual cycle. Hum Reprod 1998, 13(12):3469-3477

11. Mylonas I, Jeschke U, Wiest I, Hoeing A, Vogl J, Shabani N, Kuhn C, Schulze S, Kupka MS, Friese K: Inhibin/activin subunits alpha, beta-A and beta- $B$ are differentially expressed in normal human endometrium throughout the menstrual cycle. Histochem Cell Biol 2004, 122(5):461-471.

12. Worbs S, Shabani N, Mayr D, Gingelmaier A, Makrigiannakis A, Kuhn C, Jeschke U, Kupka MS, Friese K, Mylonas I: Expression of the inhibin/activin subunits (-alpha, -betaA and -betaB) in normal and carcinogenic endometrial tissue: possible immunohistochemical differentiation markers. Oncol Rep 2007, 17(1):97-104.

13. Mylonas I, Worbs S, Shabani N, Kuhn C, Kunze S, Schulze S, Dian D, Gingelmaier A, Schindlbeck C, Bruning A, et al: Inhibin-alpha subunit is an independent prognostic parameter in human endometrial carcinomas: analysis of inhibin/activin-alpha, -betaA and -betaB subunits in 302 cases. Eur J Cancer 2009, 45(7):1304-1314.

14. Mylonas I, Makovitzky J, Fernow A, Richter DU, Jeschke U, Briese V, Gerber $B$, Friese K: Expression of the inhibin/activin subunits alpha (alpha), beta-A (betaA) and beta-B (betaB) in benign human endometrial polyps and tamoxifen-associated polyps. Arch Gynecol Obstet 2005, 272(1):59-66

15. Mylonas I, Makovitzky J, Hoeing A, Richter DU, Vogl J, Schulze S, Jeschke U, Briese $V$, Friese $K$ : Inhibin/activin subunits beta-A (-betaA) and beta-B (-betaB) are differentially localised in normal, hyperplastic and malignant human endometrial tissue. Acta Histochem 2006, 108(1):1-11.

16. de Kretser DM, Hedger MP, Loveland KL, Phillips DJ: Inhibins, activins and follistatin in reproduction. Hum Reprod Update 2002, 8(6):529-541.

17. Welt $C$, Sidis $Y$, Keutmann $H$, Schneyer A: Activins, inhibins, and follistatins: from endocrinology to signaling. A paradigm for the new millennium. Exp Biol Med (Maywood) 2002, 227(9):724-752.

18. Risbridger GP, Schmitt JF, Robertson DM: Activins and inhibins in endocrine and other tumors. Endocr Rev 2001, 22(6):836-858.

19. Sugawara K, Kizaki K, Herath CB, Hasegawa Y, Hashizume K: Transforming growth factor beta family expression at the bovine feto-maternal interface. Reprod Biol Endocrinol 2010, 8(1):120.

20. Stoikos CJ, Salamonsen LA, Hannan NJ, O'Connor AE, Rombauts L, Dimitriadis $E$ : Activin $A$ regulates trophoblast cell adhesive properties: implications for implantation failure in women with endometriosisassociated infertility. Hum Reprod 2010, 25(7):1767-1774.

21. Florio P, Gabbanini M, Borges LE, Bonaccorsi L, Pinzauti S, Reis FM, Boy Torres P, Rago G, Litta P, Petraglia F: Activins and related proteins in the establishment of pregnancy. Reprod Sci 2010, 17(4):320-330.

22. Jones $R L$, Findlay JK, Farnworth $P G$, Robertson DM, Wallace $E$ Salamonsen LA: Activin A and inhibin A differentially regulate human uterine matrix metalloproteinases: potential interactions during decidualization and trophoblast invasion. Endocrinology 2006, 147(2):724-732.

23. Jones RL, Salamonsen LA, Findlay JK: Potential roles for endometrial inhibins, activins and follistatin during human embryo implantation and early pregnancy. Trends Endocrinol Metab 2002, 13(4):144-150.

24. Dimitriadis E, White CA, Jones RL, Salamonsen LA: Cytokines, chemokines and growth factors in endometrium related to implantation. Hum Reprod Update 2005, 11(6):613-30.

25. Florio P, Bruni L, Galleri L, Reis FM, Borges LE, Bocchi C, Litta P, De Leo V, Petraglia F: Evaluation of endometrial activin A secretion for prediction of pregnancy after intrauterine insemination. Fertil Steril 2009, 93(7):2316-2320.

26. Chang HJ, Lee JH, Hwang KJ, Kim MR, Chang KH, Park DW, Min CK: Transforming growth factor (TGF)-beta1-induced human endometrial stromal cell decidualization through extracellular signal-regulated kinase and Smad activation in vitro: peroxisome proliferator-activated receptor gamma acts as a negative regulator of TGF-beta1. Fertil Steril 2008, 90(4 Suppl):1357-1365.

27. Mellor SL, Cranfield M, Ries R, Pedersen J, Cancilla B, de Kretser D, Groome NP, Mason AJ, Risbridger GP: Localization of activin beta(A)-, beta (B)-, and beta(C)-subunits in humanprostate and evidence for formation of new activin heterodimers of beta(C)-subunit. $J$ Clin Endocrinol Metab 2000, 85(12):4851-4858

28. Mylonas I, Makovitzky J, Kunze S, Brüning A, Kainer F, Schiessl B: InhibinbetaC subunit expression in normal and pathological human placental tissues. Syst Biol Reprod Med 2010.

29. Weissenbacher T, Bruning A, Kimmich T, Makovitzky J, Gingelmaier A, Mylonas I: Immunohistochemical labeling of the inhibin/activin betaC subunit in normal human placental tissue and chorionic carcinoma cel lines. J Histochem Cytochem 2010, 58(8):751-757.

30. Käufl SD, Makovitzky J, Kuhn C, Kunze S, Jeschke U, Mylonas I: Inhibin/ activin-betaC subunit in human endometrial adenocarcinomas and HEC1a adenocarcinoma cell line. In Vivo 2010, 282:185-191.

31. Kimmich T, Bruning A, Kaufl SD, Makovitzky J, Kuhn C, Jeschke U, Friese K, Mylonas I: Inhibin/activin-betaC and -betaE subunits in the Ishikawa human endometrial adenocarcinoma cell line. Arch Gynecol Obstet 2010, 282(2):185-191.

32. Käufl SD, Kuhn C, Kunze S, Shabani N, Bruning A, Friese K, Mylonas I: Inhibin/activin-betaC subunit does not represent a prognostic parameter in human endometrial cancer. Arch Gynecol Obstet 2010. 
33. Blankenstein TJF, Jückstock JK, Shabani N, Kunze S, Brüning A, Bergauer $F$, Mylonas I: Immunolabelling of the inhibin/activin-betaC subunit in normal and malignant human uterine cervical tissue and cervical cancer cell lines. Oncol Rep 2010.

34. Gingelmaier A, Bruning A, Kimmich T, Makovitzky J, Bergauer F, Schiessl B, Friese K, Mylonas I: Inhibin/activin-betaE subunit is expressed in normal and pathological human placental tissue including chorionic carcinoma cell lines. Arch Gynecol Obstet 2010.

35. Mylonas I, Shabani N, Vogl J, Makovitzky J, Kunze S, Kuhn C, Schulze S, Friese $\mathrm{K}$, Jeschke $\mathrm{U}$ : Inhibin/activin subunits are immunohistochemically expressed in complete and partial hydatidiform moles. Anticancer Res 2007, 27(4A):1995-2000.

36. Bergauer F, Bruning A, Shabani N, Blankenstein T, Juckstock J, Dian D, Mylonas I: Inhibin/activin-betaE subunit in normal and malignant human cervical tissue and cervical cancer cell lines. J Mol Histol 2009, 40(56):353-359.

37. Tsuchida K, Nakatani M, Hitachi K, Uezumi A, Sunada Y, Ageta H, Inokuchi K: Activin signaling as an emerging target for therapeutic interventions. Cell Commun Signal 2009, 7:15.

38. Mylonas I, Jeschke U, Kunert-Keil C, Shabani N, Dian D, Bauerfeind I, Kuhn C, Kupka MS, Friese K: Glycodelin A is expressed differentially in normal human endometrial tissue throughout the menstrual cycle as assessed by immunohistochemistry and in situ hybridization. Fertil Steril 2006, 86(5):1488-1497

39. Noyes RW, Hertig AT, Rock J: Dating the endometrial biopsy. Fertil Steril 1950, 1:3-15.

40. Mylonas I, Speer R, Makovitzky J, Richter DU, Briese V, Jeschke U, Friese K: Immunohistochemical analysis of steroid receptors and glycodelin $\mathrm{A}$ (PP14) in isolated glandular epithelial cells of normal human endometrium. Histochem Cell Biol 2000, 114(5):405-411.

41. Mylonas I, Makovitzky J, Shabani N, Gingelmaier A, Dian D, Kuhn C, Schulze S, Kunze S, Jeschke U, Friese K: Development and characterisation of an antibody for the immunohistochemical detection of inhibin/activin betaE (betaE) in normal human ovarian and placental tissue. Acta Histochem 2009, 111(4):366-371.

42. Mylonas I: Inhibin-alpha, -betaA and -betaB subunits in uterine nonendometrioid carcinomas: Prognostic significance and clinical implications. Eur J Cancer 2010, 46(13):2485-2493.

43. Mylonas I: Inhibin-betaA subunit immunolabeling as a prognostic factor in endometrioid adenocarcinomas: a matter of evaluation? Arch Gynecol Obstet 2010.

44. Mylonas I, Jeschke U, Shabani N, Kuhn C, Friese K, Gerber B: Inhibin/activin subunits (inhibin-alpha, -betaA and -betaB) are differentially expressed in human breast cancer and their metastasis. Oncol Rep 2005, 13(1):81-88.

45. Jückstock K, Brüning A, Blankenstein T, Kunze S, Shaban N, Bergauer F Mylonas I: Immunolabelling of the inhibin-betaA and -betaB subunit in normal and malignant human cervical tissue and cervical cancer cell line. Int J Gynecol Cancer 2010, 20(7):1177-1125.

46. Mylonas I, Schiess B, Jeschke U, Vogl J, Makrigiannakis A, Kuhn C, Kunze S, Schulze $S$, Kainer $F$, Friese $K$ : Expression of inhibin/activin subunits alpha (-alpha), beta A (-beta $(A))$ and beta B (-beta (B)) in placental tissue of normal and intrauterine growth restricted (IUGR) pregnancies. $J \mathrm{Mol}$ Histol 2006, 37(1-2):43-52.

47. Mylonas I, Schiessl B, Jeschke U, Vogl J, Makrigiannakis A, Kuhn C, Schulze S, Kainer F, Friese K: Expression of inhibin/activin subunits alpha (-alpha), betaA (-betaA), and betaB (-betaB) in placental tissue of normal, preeclamptic, and HELLP pregnancies. Endocr Pathol 2006, 17(1):19-33.

48. Lau AL, Kumar TR, Nishimori K, Bonadio J, Matzuk MM: Activin betaC and betaE genes are not essential for mouse liver growth, differentiation, and regeneration. Mol Cell Biol 2000, 20(16):6127-6137.

49. Ferreira MC, Cavallo IK, Florio P, Petraglia F, Reis FM: Activin betaA subunit, follistatin and follistatin-like 3 are expressed in the endometrium of ovariectomized rats and regulated by estrogen replacement. $J \mathrm{Mol}$ Histol 2008, 39(5):535-541.

50. Ni X, Luo S, Minegishi T, Peng C: Activin A in JEG-3 cells: potential role as an autocrine regulator of steroidogenesis in humans. Biol Reprod 2000, 62(5):1224-1230

51. Menkhorst E, Salamonsen LA, Zhang J, Harrison CA, Gu J, Dimitriadis E: Interleukin 11 and activin $A$ synergise to regulate progesterone-induced but not cAMP-induced decidualization. J Reprod Immunol 2010, 84(2):124-132.
52. Caniggia I, Lye SJ, Cross JC: Activin is a local regulator of human cytotrophoblast cell differentiation. Endocrinology 1997, 138(9):3976-3986

53. Keelan JA, Zhou RL, Mitchell MD: Activin A exerts both pro- and antiinflammatory effects on human term gestational tissues. Placenta 2000, 21(1):38-43.

54. Beattie GM, Lopez AD, Bucay N, Hinton A, Firpo MT, King CC, Hayek A Activin A maintains pluripotency of human embryonic stem cells in the absence of feeder layers. Stem Cells 2005, 23(4):489-495.

55. Sulzbacher S, Schroeder IS, Truong TT, Wobus AM: Activin A-Induced Differentiation of Embryonic Stem Cells into Endoderm and Pancreatic Progenitors-The Influence of Differentiation Factors and Culture Conditions. Stem Cell Rev 2009, 5(2):159-173.

56. Chen YG, Lui HM, Lin SL, Lee JM, Ying SY: Regulation of cell proliferation, apoptosis, and carcinogenesis by activin. Exp Biol Med (Maywood) 2002, 227(2):75-87.

57. Esquela AF, Zimmers TA, Koniaris LG, Sitzmann JV, Lee SJ: Transient downregulation of inhibin-betaC expression following partial hepatectomy. Biochem Biophys Res Commun 1997, 235(3):553-556.

58. Zhang YQ, Shibata $H$, Schrewe H, Kojima I: Reciprocal expression of mRNA for inhibin betaC and betaA subunits in hepatocytes. Endocr J 1997, 44(5):759-764.

59. Ushiro $Y$, Hashimoto O, Seki M, Hachiya A, Shoji H, Hasegawa Y: Analysis of the Function of Activin beta(C) Subunit Using Recombinant Protein. $J$ Reprod Dev 2006, 52(4):487-495.

60. Chabicovsky M, Herkner K, Rossmanith W: Overexpression of activin beta (C) or activin beta(E) in the mouse liver inhibits regenerative deoxyribonucleic acid synthesis of hepatic cells. Endocrinology 2003 144(8):3497-3504.

61. Vejda S, Erlach N, Peter B, Drucker C, Rossmanith W, Pohl J, SchulteHermann R, Grusch M: Expression of activins $C$ and $E$ induces apoptosis in human and rat hepatoma cells. Carcinogenesis 2003, 24(11):1801-1809.

62. Wada W, Medina JJ, Kuwano H, Kojima I: Comparison of the function of the beta(C) and beta(E) subunits of activin in AML12 hepatocytes. Endocr J 2005, 52(2):169-175.

63. Gold EJ, Zhang X, Wheatley AM, Mellor SL, Cranfield M, Risbridger GP, Groome NP, Fleming JS: betaA- and betaC-activin, follistatin, activin receptor $\mathrm{mRNA}$ and betaC-activin peptide expression during rat liver regeneration. J Mol Endocrinol 2005, 34(2):505-515.

64. Gold E, Jetly N, O'Bryan MK, Meachem S, Srinivasan D, Behuria S, Sanchez-

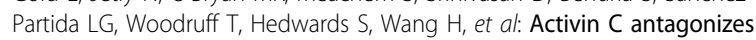
activin $\mathrm{A}$ in vitro and overexpression leads to pathologies in vivo. Am J Pathol 2009, 174(1):184-195.

65. Mellor SL, Ball EM, O'Connor AE, Ethier JF, Cranfield M, Schmitt JF, Phillips DJ, Groome NP, Risbridger GP: Activin betaC-subunit heterodimers provide a new mechanism of regulating activin levels in the prostate. Endocrinology 2003, 144(10):4410-4419.

66. Butler CM, Gold EJ, Risbridger GP: Should activin betaC be more than a fading snapshot in the activin/TGFbeta family album? Cytokine Growth Factor Rev 2005, 16(4-5):377-385.

67. O'Bryan MK, Sebire KL, Gerdprasert O, Hedger MP, Hearn MT, de Kretser DM: Cloning and regulation of the rat activin betaE subunit. $J \mathrm{Mol}$ Endocrinol 2000, 24(3):409-418.

68. Takamura K, Tsuchida K, Miyake H, Tashiro S, Sugino H: Activin and activin receptor expression changes in liver regeneration in rat. J Surg Res 2005, 126(1):3-11.

69. Rodgarkia-Dara C, Vejda S, Erlach N, Losert A, Bursch W, Berger W, SchulteHermann $R$, Grusch M: The activin axis in liver biology and disease. Mutat Res 2006, 613(2-3):123-137.

doi:10.1186/1477-7827-8-143

Cite this article as: Mylonas et al:: Evidence of inhibin/activin subunit betaC and betaE synthesis in normal human endometrial tissue. Reproductive Biology and Endocrinology 2010 8:143. 